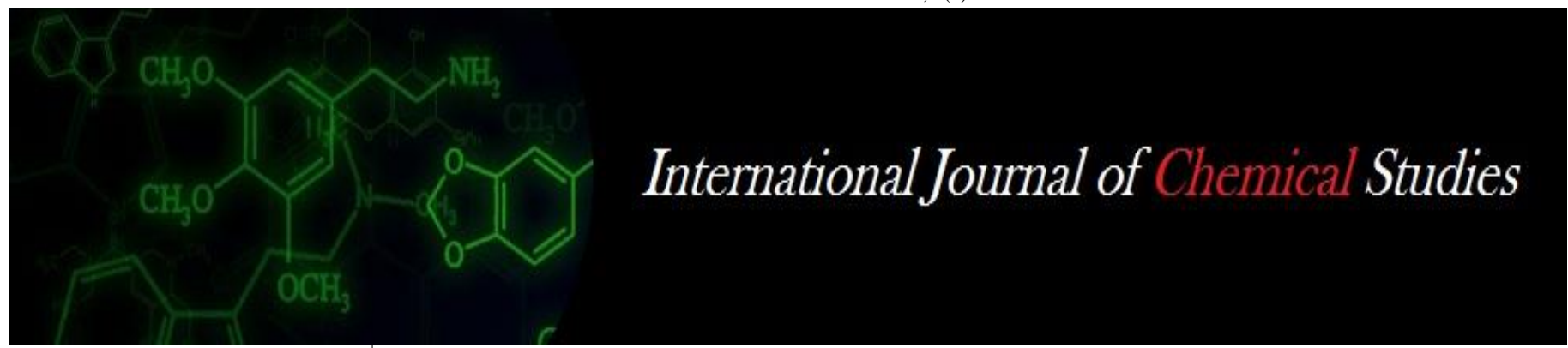

P-ISSN: 2349-8528

E-ISSN: 2321-4902

www.chemijournal.com

IJCS 2020; 8(3): 955-957

(C) 2020 IJCS

Received: 19-03-2020

Accepted: 20-04-2020

\section{PN Madavi}

Department of Plant Pathology,

Post Graduate Institute, Dr.

Panjabrao Deshmukh Krishi

Vidhyapeeth, Akola,

Maharashtra, India

\section{Totawar}

Department of Plant Pathology,

Post Graduate Institute, Dr.

Panjabrao Deshmukh Krishi

Vidhyapeeth, Akola,

Maharashtra, India

SS Mane

Department of Plant Pathology,

Post Graduate Institute, Dr.

Panjabrao Deshmukh Krishi

Vidhyapeeth, Akola,

Maharashtra, India
Corresponding Author:

\section{PN Madavi}

Department of Plant Pathology,

Post Graduate Institute, Dr.

Panjabrao Deshmukh Krishi

Vidhyapeeth, Akola,

Maharashtra, India

\section{Reaction of different acid lime cultivars to isolates of Xanthomonas axonopodis pv. Citri}

\author{
PN Madavi, MV Totawar and SS Mane
}

DOI: https://doi.org/10.22271/chemi.2020.v8.i31.9323

\begin{abstract}
In present research work eight different isolates of Xanthomonas axonopodis pv. citri were tested on different acid lime cultivars. The pathogenicity was confirmed by reaction of these isolates on different citrus cultivars by inoculation. The water soaked lesions along with fully developed symptoms were developed after 9 to 12 days of inoculation. The Xac1 was highly virulent and Xac2, Xac4, Xac5, Xac6 were poor virulent and Xac3, Xac7, Xac8 were moderately virulent.
\end{abstract}

Keywords: Xanthomonas axonopodis, Citri, isolates

\section{Introduction}

Citrus canker is one of the most destructive and predominant on acid lime in Vidarbha region of Maharashtra. Citrus bacterial canker (CBC), caused by Xanthomonas citri subsp citri (Schaad et al. 2006) ${ }^{[8]}$ is one of the most devastating diseases through the world that affects many kind of commercial citrus varieties. It was first identified in Florida (USA) in 1915 and in India was reported from Punjab in 1942. The main symptoms of CBC are hyperplasia-type lesions on leaves, fruit and stems. In severe infections causes leaf abscission, twig dieback and premature fruit drop (Stall and Civerolo 1991; Gottwald et al. 1993) ${ }^{[9,3]}$. The bacterium was first named as Pseudomonas citri (Hasse, 1915) ${ }^{[5]}$. In 1939 it was classified as genus Xanthomonas sp. (X. citri), then reclassified in 1980 (Dye et al., 1980) ${ }^{[2]}$ as Xanthomons campestris pv. citri due to inadequate phenotypic data (Young et al., 1978) ${ }^{[11]}$.

There are many types of citrus canker caused by various pathovars and variants of the bacterium Xanthomonas axonopodis (Graham et al., 1990) ${ }^{[4]}$. All cultivars of citrus are susceptible to canker, but grapefruit, Mexican lime and lemon are highly susceptible, whereas sour orange and sweet orange are moderately susceptible. Mandarins are moderately resistant (Gottwald et al., 1993) [3]. All young, above-ground tissues of citrus are susceptible to Xanthomonas axonopodis. In fact, bacterial pathogens infects into the plant tissues through natural openings (stomata) and mechanical injuries (wounds).

Xanthomonas axonopodis pv. citri is a rod shaped gram negative bacterium with single polar flagellum. It is obligatorily aerobic, non spore former and produce yellow colonies on NA medium. The maximum temperature for growth is 35 to $39^{\circ} \mathrm{C}$ (Mehrotra, 1980; Whiteside et al., 1988) ${ }^{[6,10]}$.

The present investigation was undertaken for reaction of different acid lime cultivars to the different isolates of Maharashtra region.

\section{Material and Methods}

Collection and isolation of diseased plant samples

The disease sample infected with citrus canker collected from different locations of Maharashtra regions. viz. Gadchiroli, Yavatmal, Bhandara, Akola, Nagpur, Pune, Gondia, Solapur etc. The samples of acid limes infected with citrus canker were colleted during July October 2014. The fresh infected leaves sample were used for isolation by empolying tissue isolation method on NA medium.

\section{Pathogenecity test}

Preparation of bacterial culture

The eight pure bacterial isolates of Xanthomonas axonopodis pv. citri viz. Xac 1, 2, 3, 4, 5, 6, 7,8 to be tested were inoculated on NA medium for. 
The cultures were incubated cultures at $250 \mathrm{C}$ for 3 to 5 days prior to inoculation. The $48 \mathrm{hrs}$ old culture was used for the inoculation on NA medium.

Inoculation of bacterial culture Four varieties of acid lime viz. Chakradhar, Pramalini, Tahiti and Vikram were selected. The seedlings/ grafts. Were used for inoculation of each isolate separately. Inoculation was done by smearing the bacterial culture on leaves at 10 injury points made by pin prick method. The plants were maintained under humid condition. The observations were recorded on the basis of number of pricks made and number of spots exhibited diseased symptoms. Uninoculated injured plants treated with sterilized water surved as control.

\section{Results and Discussion}

Table 1: Location of diseased samples

\begin{tabular}{|c|c|c|}
\hline S. No & Location & Code no. \\
\hline 1 & Gadchiroli & Xac1 \\
\hline 2 & Yavatmal & Xac2 \\
\hline 3 & Bhandara & Xac3 \\
\hline 4 & Akola & Xac4 \\
\hline 5 & Nagpur & Xac5 \\
\hline 6 & Pune & Xac6 \\
\hline 7 & Gondia & Xac7 \\
\hline 8 & Solapur & Xac8 \\
\hline
\end{tabular}

Reaction of these isolates on the different citrus cultivars.

Table 2: Reaction of different acid lime cultivars to isolates of Xanthomonas axonopodis pv.citri

\begin{tabular}{|c|c|c|c|c|c|c|c|c|}
\hline \multicolumn{6}{|c|}{ Days to initiate water soaked lesions by xac isolates } \\
\hline Varieties of acid lime & Xac1 & Xac2 & Xac3 & Xac4 & Xac5 & Xac6 & Xac7 & Xac8 \\
\hline Chakradhar & 3 & 3 & 4 & 6 & 4 & 7 & 5 & 7 \\
\hline Vikram & 3 & 4 & 6 & 7 & 8 & 5 & 7 & 4 \\
\hline Pramalini & 4 & 3 & 7 & 6 & 5 & 8 & 7 & 8 \\
\hline Tahiti & 0 & 0 & 0 & 0 & 0 & 0 & 0 & 0 \\
\hline
\end{tabular}

Eight isolates of Xanthomonas axonopodis pv. citri (Table 2) were assessed for their reactions on acid lime four cultivars viz Chakradhar, Vikram, Pramalini, Tahiti by inoculating their pure culture by culture smearing on the leaves. The results (Table 2 and Plate 8) revealed that the test isolates of $X$. axonopodis pv. citri were able to induce canker disease on only three verities of acid lime under artificial inoculation condition, except Tahiti. Isolates Xac1 and Xac2 represented distinct nature of virulence as it initiated water soaked lession within four days of inoculation on Chakradhar, Vikram and Pramalini. While other isolates Xac2, Xac4, Xac5, Xac6 were poor virulent and Xac3, Xac7, Xac8 were moderately virulent.

Tahiti was found resistant against all isolates as none of the isolate was able to cause the disease. Rest of the three acid lime varieties viz. Chakradhar, Pramalini and Vikram showed susceptible reaction to test isolates. Overall, isolate Xac1 was found more aggressive and virulent, followed by other isolates.

These findings are similar to the results of Das, (2002) ${ }^{[1]}$ who reported pathogenic variability among the isolates of Xanthomonas axonopodis pv. citri and categorized them based on their virulence as highly virulent, moderately virulent and less virulent. Variable reaction of Xanthomonas axonopodis pv. citri on citrus varieties were also recorded by
Prasad et al. (1978) ${ }^{[7]}$, which can be used to differentiate the group of isolate into strains.

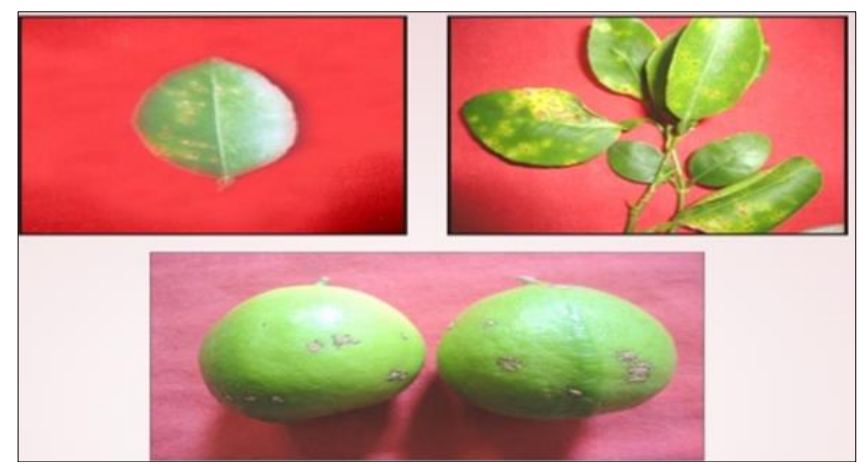

Plate 1: Symptoms of citrus canker on leaves, twigs and fruits

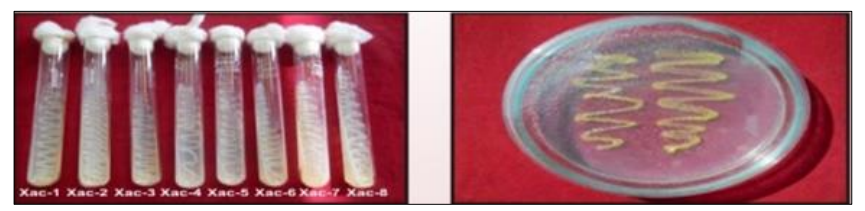

Plate 2: Isolates if xanthomonas axonopodis pv. Nutrient agar medium

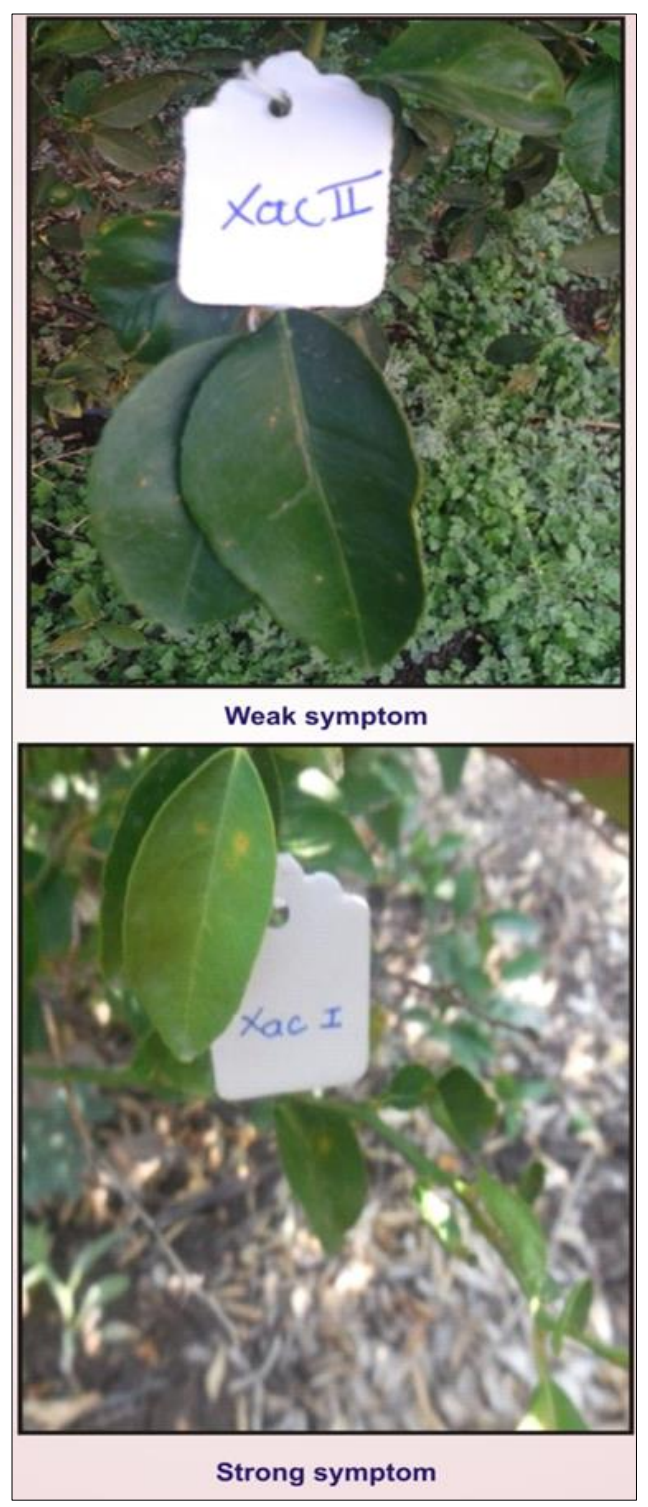

Plate 3: Reaction of isolates on different citrus cultivars 


\section{References}

1. Das AK. Pathogenic variability of Xanthomonas axonopodispv. citricausalagent of citrus canker. J Mycol. Pl. Pathol. 2002; 17(2):175-178.

2. Dye DW, Bradbury JF, Goto M, Hayward AC, Lelliot RA, Schroth MN. International standards for naming pathovars of phytopathogenic bacteria and a list of pathovar names and pathotype strains. Rev. Plant Pathol. 1980; 59(4):153-168.

3. Gottwald TR, Graham JH, Civerolo EL, Barret HC, Hearn CJ. Differential host range reaction of citrus and citrus relatives to citrus canker and citrus bacterial spot determined by leaf mesophyll susceptiblity. Plant Dis. 1993; 77:1004-1009.

4. Graham JH, Gottwald TR. Variation in aggressiveness of Xanthomonas campastries pv. citrumelo associated with citrus bacterial spot in Florida citrus nurseries. Phytopath. 1990; 80:190-196.

5. Hasse CH. Pseudomonas citri, the cause of citrus canker J Agric. Res. 1915; 4:97-100.

6. Mehrotra RS. Bacteria and Bacterial Diseases. Plant Pathology. Tata McGraw-Hill pub. Co. Ltd. New Delhi, 1980, 636-8.

7. Prasad MVR, Moses GJ, Reddy GS. Variability in Xanthomonas citri the incitent of citrus canker. Indian Phytopath. 1978; 31:227-229.

8. Schaad NW, Postnikova E, Lacy G, Sechler A, Agarkova I, Stromber PE et al. Emended classification of Xanthomonas pathogens on citrus. Syst Appl. Microbiol. 2006; 29:690-695.

9. Stall RE, Civerolo EL. Research relating to the recent outbreak of citus canker in Florida. Ann. Rev. Phytopathol. 1991; 29:399-420.

10. Whiteside JO, Garney SM, Timmer LW. Compendium of citrus diseases. The American Phytopathological Society, 1988, 80 .

11. Young JM, Dye DW, Bradbury JF, Panagopoulos CG, Robbs CF. A proposed nomenclature and classification for plant pathogenic bacteria. New Zealand J Agric. Res. 1978; 21:153-177. 